\title{
諲竟
}

\section{造船溶接における技術革新の今後のありかたとこれに 付随する問題点ならびにその対策に関する考察(補遺)}

\author{
山本登, 寺井清
}

\author{
Innovation of Welding in Shipbuilding and Observation
}

About the Problems Annexed to its Application (Supplement)

by Noboru Yamamoto and Kiyoshi Terai

\section{第 4 章 自動化概論}

\section{1. まえがき}

以上 3 章にわたって篗者は造船溶接の技術革新の今後 を指问するとともに，その導入体制のあり加た沉言及し た.しかしてれらにおいては議論を完全な形のむのとし たいと努力すればするほどその思考の過程は朴貿的な諭 理形体をとらざるを得ず，いきおい箩者の述へるる説明が 難解な文体となったことは否めないと思う。梀章におい ては上述の久を補うべく，造船溶接の自動化を事例に上 ってその具体例を示し，あわせて等者の説く澢接技術管 理を解説する手段の 1 助としたいと考える.

さて図一12は最近 3 年間における全国主要造船所の溶 接近代化の進展状況を自動化率ならびに專用化深により

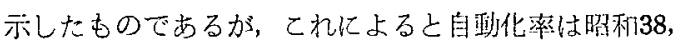
39，40年にわたって12.1，12.7，12.3\% と $12 \%$ 台を低迷 している．特に40年に $12.3 \%$ とわずかながらも前牛から 後退したことは，漫近は船台工程の溶揬自動化の熱が高 まっている折枑だけに，意外とも遗憾ともいうべき絬果 といえよう。

むっと屯この点について造船では船体楧造の大きさ， 複雑さを説く以前の問題として溶接長で全体の80\%を占

原稳受付 昭和 41 年 7 月 23 日

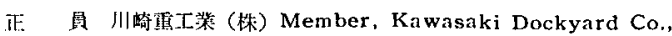
Ltd.

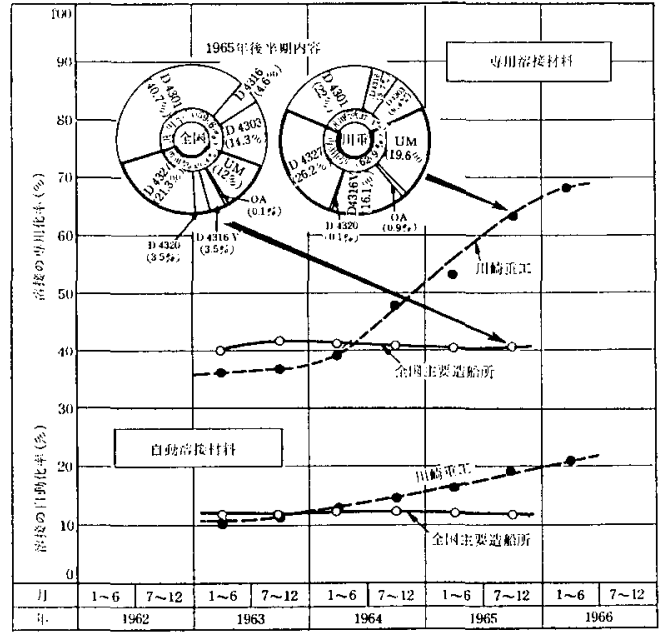

図一12 造船溶接の自動化，專用化に関寸万最 近の変還

めるととろのスミ肉継手をすべて高能率な專用棒で溶揬 しているから，自動化萑が他産業より低いとの意見もだ されるかもし机ない.しかし篗者の造船所に批いてお なじく図-12に示すごとくむちろん笑合継手にかぎって の㪊であるにもかかわらず，自動化率は年々䄇实に $3 \%$ 程度の增打をみせており昭和40华平均で $17 \%$ ，さらに同 年末現在においては20\%台を超えるとてろにまでいたっ ている。しかもいっぽうスミ肉溶接をはじめとする手溶

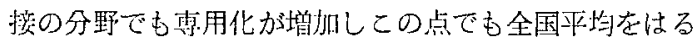


かに上回る現状にある。ただし筆者がこれらの成果を得 た理由の最大のものは個々の新しい技術改善の探求に由 来することはもちろんではあるが，また同時にこれらの 導入に際して巨視的立場からそれぞれの造船における比 重を比較榆討してその推進に閔して綜合们計西を確立し たからに加ならない。

以下にその大要について示し諳者の御参考に供した w.

\section{2.溶接自動化の綜合的計画}

船体の溶接はも方万ん内業, 地上, 船台の 3 工程に分 けて施工されるが，そのそれぞれにおいてごの範囲まで の溶接が自動化されるであろうかを巨視的な態度で諭じ た資料は少なくむ現在までのところではみあたらないよ うである、表一5はこのような初心者的な疑間に答えて 作製した結果であるが，このような primitive とあ思元 るものが䍐雪には案外不明のままのこされることが多い のでいまここにその大要を説明しておてう。すなわち表 ー5ではまず継手を工程別ならびに部忉の種別に18בの グループ（群）に分類している．ただしすでに述へた理 由から自動化の刘象はすべて突合継手にかぎっており， スミ肉継手は専用型溶揬棒によるむのとしててこでは議 諭の対象からはずしておく.さてての場合溶接姿勢には 上向をのぞくすべてが佱まれるが，上问の場合は結局は 下向の外面溶接で解決さ扎ると考えて終局的には下问に 含めるてとになる。そして下向にはユニオンメルト法を 主として使用するが，乙机の補助手段としてたとえばシ ーリングビードなどにオープンアーク法を㴊用すること がある。また站河にはエレクトロスラグ法，エレクトロ ガス法あるいは消耗ノズル式エレクトロスラグ法が使用 さ机るであるうし，さらに横们にはユニオンメルト洼， $\mathrm{CO}_{2}$ ガスアーク法, オープンアーク法のうちのいずれか が適用されることになるう。つぎ適用の刘象となる部 材の種類であるが，これはそれぞれに刘する自動化率が 経験之計算から定星湖に把握できるかぎりにおいて細分 化したものである。この結果内業, 地上, 船台の各工程 はそれぞれ $2 ， 3 ， 13 \sqsupset の$ 群に分割されるのであるが， 各萑には参考までにそ㣗ぞれの継手の工事量の大体の基 集（criterion）を付䛉しておいた。

以上からいま自蜼化の推進限界をなが多ると，内業の 小組立工程に求いては約 $4 \%$ ，また地上の大組立工程に おいては15\%となり，結局定盤上工事のみでも19\%の多 きに上るが，いっぽう難度のいちじるしく大きいと考元 られる船台工程では稚数こそ多いが自動化率の合計はせ いぜい $7 \%$ にすぎず，しかむその半数ちかくは上甲板や 底部外板のバットとシームに集中されているから，結局 自動化の効果を定量的にみるかするいはまた定性的にみ
るかによってそのアプローチの意義には千差が生じるこ ととなろう。たとえば現在のところ造船汇抢ける自動化 率の全国平均值は12\%台であるからこれのすべてが定盤 上工事により求められた数字であるとしても，難度の比 較的少ない定船での自動化はなお $7 \%$ ちかくがのてされ ることになり，て机のみでも船台上工事で求められる全 部に匹敵する。もち万ん技術者としての立場加らいえ ば，技術的に難度の大きいものほどそれをのりてえてす すむときのよろこびは大きいにはちがいないであ万うけ れごも，いま観点を生産性のうち最大の魅力と考えられ る能萍向上にしばれば，この点に対する自動化の綜合的 効果はもち万ん自動化率の大きいものほど大であるか ら，この定盤上にのこされた $7 \%$ という数字はなにより もさきに処理されてしかるべきであろう.

とまれ自動化の限界はこういった点のすべてを解決し て屯なお26\%すなわち全体の 4 分の1程度にすぎない。 しかし欧州の造船所ではブロックの大組立に際してロン ヂ材と板材との取合のスミ肉継手にも自動溶接を適用し ているのでこ机を尃用溶接棒（主として D 4327）に上 り施工しているわが国造船所と外国の造船所の双方の結 果を単純に比較することは罗当でないし，またて机つ いての詳細の議論牥別の機会にゆずるととにするが，た とえ上記のスミ肉に自動溶接を適用しても自動化率はせ いぜい12\%程度であるから，以上を綜合しても自動化率 の最大限は38\%どまりであるということになる。

\section{3. 自動化推進上の問題点}

さて表一5には溶接の自動化に際して解決しなければ なら始ところの定性的な問題点の内容をむ明らかにして いるので，いまこ机についてその詳細をながめてみよ う.ただし問題点は溶接材料と溶接機器の両者にあると 诺えられ第 1 群から第18群までにはそれぞれ異なったも のが示されているが. このながは多くの其通した因子 とたとえ単独でも自動化率の大きいものでは影響すると ころが大きいのでこの点から表- 5 に示す問題点をまと めてみると溶接材料面では（1）片面自動化，（2）高 能率化, (3) 対傾斜性の改善の 3 点, また溶接機器面 では（4）溶接機の可搬性の改善, (5) 高能率化,

（6）へッドの登はん能力の改普，（7）半自動溶接の 实用化の 4 点となり，このうち（2）上（5）ならびに （3）上（6）はそれぞれおなじ团子亡なるから，大き な問題点は大体 5 コということになる。いまとれら問題 点を発生するための母体となった造船所の周匀状況につ いて順をおってながめてみよう。

\section{1 片面自動化}

ての方法についてはすでに一般の認識がふかく尚らた めて詳細在説明するまですあるまい，しかし継手の単位 
表一-5 船体溶接の自動化の進展内容とこれに付随する溶接固有の問題点

\begin{tabular}{|c|c|c|c|c|c|c|c|c|c|c|c|}
\hline \multirow{2}{*}{ 群 } & \multirow{2}{*}{ 工柽 } & \multirow{2}{*}{ 溶按裘勢 } & \multirow{2}{*}{ 溶 接 法 } & \multirow{2}{*}{ 適 用 対 象 } & \multicolumn{3}{|c|}{ 溶 接 工 恋 量 } & \multicolumn{2}{|c|}{ 自動溶接燠用上の問題点 } & \multirow{2}{*}{\multicolumn{2}{|c|}{$\begin{array}{l}\text { 自酣 化 率 } \\
\text { (溶接材料董量比) }\end{array}$}} \\
\hline & & & & & 巣位継手展 & 板 原 & 频度 & 溶接材料面 & 溶接機舆面 & & \\
\hline 1 & 内深 & 下 闬 & UM & 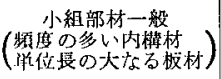 & $2-12 \mathrm{~m}$ & $12 \sim 30 \mathrm{~mm}$ & - & な $L$ & ヘッドの軽雷化 & $2 \%$ & \multirow[b]{2}{*}{$4 \%$} \\
\hline 2 & $"$ & $" l$ & $"$ & 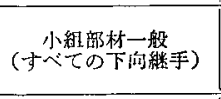 & 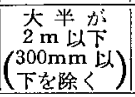 & $\begin{array}{l}\text { 火米h } \\
20 \mathrm{~mm} \\
\text { 以下 }\end{array}$ & 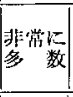 & 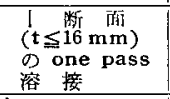 & $\begin{array}{c}\text { ヘッドの軽是化 } \\
(\mathrm{A}, \mathrm{B} \text { 䄲 })\end{array}$ & $2 \%$ & \\
\hline 3 & 地上 & $" \prime$ & $"$ & $\begin{array}{l}\text { 平面ブロックの板 } \\
\text { つぎ }\end{array}$ & $12 \sim 16 \mathrm{~m}$ & $12 \sim 30 \mathrm{~mm}$ & $"$ & 片面自野化 & 高能無化 & $\sim 9 \% \sim$ & \multirow{3}{*}{$15 \%$} \\
\hline 4 & $" \prime$ & $\begin{array}{c}\text { 售下们 } \\
\left(\begin{array}{c}\text { 傾 斜 } \\
7^{\circ} \times 7^{\circ}\end{array}\right)\end{array}$ & $\mathrm{UM}, \mathbf{O A}$ & 曲门外 板 & $\sim 10 \mathrm{~m} \sim$ & $15-22 \mathrm{~mm}$ & 比較的 & 対倾斜性の改翌 & 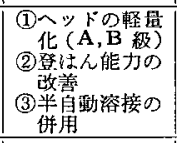 & $5 \%$ & \\
\hline 5 & $"$ & 下 & UM & ビルテ外枢。 & $12 \sim 16 \mathrm{~m}$ & $25 \sim 30 \mathrm{~mm}$ & $"$ & な 2 & $\begin{array}{c}\text { ヘッドの軽留化 } \\
(\mathrm{B}, \mathrm{C} \text { 級 }\end{array}$ & $1 \%$ & \\
\hline 6 & 船台 & (礶小傾斜) & $"$ & 底部外板シーム & $3-16 m$ & & $"$ & 怙自自期化 & $\begin{array}{c}\text { ヘッドの蹬量化 } \\
\text { (A級) }\end{array}$ & \multirow{2}{*}{$2 \%$} & \multirow{6}{*}{$5 \%$} \\
\hline 7 & $" \prime$ & " & UM, OA & 底部外板パット & $0.5 \sim 1 \mathrm{~m}$ & " & 多 数 & $"$ & 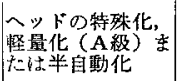 & & \\
\hline 8 & 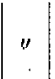 & $" \prime$ & $"$ & $\begin{array}{l}\text { ボットムッンヂの } \\
\text { フランヂ材 }\end{array}$ & $\sim 150 \mathrm{~mm} \sim$ & $\sim 25 \mathrm{~mm} \sim$ & $"$ & $"$ & 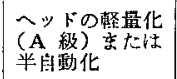 & $\sim 0.2 \% \sim$ & \\
\hline 9 & $" \prime$ & $n$ & $\mathrm{UM}$ & $\begin{array}{l}\text { サイドロンデのウ } \\
\text { エッブ材 }\end{array}$ & $-500 \mathrm{~mm} \sim$ & $12 \sim 15 \mathrm{~mm}$ & $" \prime$ & $"$ & $" \prime$ & $\sim 0.3 \% \sim$ & \\
\hline 10 & $" \prime$ & $"$ & $" \prime$ & 上丑板 & $10 \sim 16 \mathrm{~m}$ & $25 \sim 30 \mathrm{~mm}$ & $\begin{array}{l}\text { 帅較的 } \\
\text { 多 }\end{array}$ & $"$ & 高能芓化 & $2 \%$ & \\
\hline 11 & $"$ & $" \prime$ & $"$ & 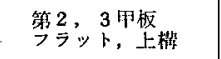 & $2 \sim 10 \mathrm{~m}$ & $10 \sim 20 \mathrm{~mm}$ & 若 $\mp$ & $"$ & $\begin{array}{l}\text { 人ットの軽量化 } \\
(\mathrm{A}, \mathrm{B} \text { 級) }\end{array}$ & $\sim 0.5 \% \sim$ & \\
\hline 12 & $"$ & itc [ab & $\mathrm{ES}, \mathrm{EG}$ & 側 僙 䋑 & $14-21 \mathrm{~m}$ & $18 \sim 22 \mathrm{~mm}$ & $"$ & 高指 察 化 & 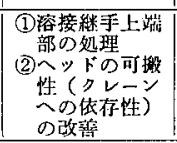 & $\sim 0.4 \% \sim$ & \multirow{5}{*}{$\sim 1.5 \% \sim$} \\
\hline 13 & $"$ & $"$ & $"$ & (檤 緑 継 壁) & " & $\mid$\begin{tabular}{c|}
$\bullet$ \\
$12 \sim 18 \mathrm{~mm}$
\end{tabular} & $"$ & $" \prime$ & $\begin{array}{l}\text { 板原部に対なる } \\
\text { 処布 }\end{array}$ & $\sim 0.3 \% \sim$ & \\
\hline 14 & $" \prime$ & 準立向 & $"$ & $\begin{array}{llll}\text { 曲 } & \vdots & \text { 外 } & \text { 板 } \\
\text { (横 } & \text { 紭 } & \text { 手) }\end{array}$ & $5 \sim 22 \mathrm{~m}$ & $"$ & $" \prime$ & " & $\begin{array}{l}\text { オーパーハング } \\
\text { 朋面の溶接に奶 } \\
\text { ナるへッドの特 } \\
\text { 殊化 }\end{array}$ & $\sim 0.2 \% \sim$ & \\
\hline 15 & $" \prime$ & It [ri] & CES & 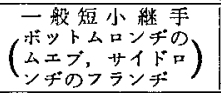 & $0.5 \sim 1 \mathrm{~m}$ & $15 \sim 20 \mathrm{~mm}$ & 多 数 & $\begin{array}{l}\text { プクスタート } \\
\text { 敄の処理 }\end{array}$ & ヘッドの軽照化 & $\sim 0.3 \% \sim$ & \\
\hline 16 & $\prime \prime$ & $"$ & $"$ & $\begin{array}{c}\text { デッキロンヂのウェプ } \\
\text { (デッキ板厚を含さ） }\end{array}$ & $300 \sim 500 \mathrm{~mm}$ & $25 \sim 30 \mathrm{~mm}$ & $"$ & - & 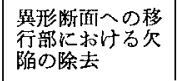 & $\sim 0.3 \% \sim$ & \\
\hline 17 & $"$ & 菇 向 & $\begin{array}{l}\mathrm{UM} \\
\mathrm{OA}\end{array}$ & 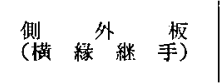 & $12 \sim 16 \mathrm{~m}$ & $18 \sim 22 \mathrm{~mm}$ & 若 于 & 片面自怔化 & $\begin{array}{l}\text { (1)高能率化 } \\
\text { (2) } \\
\text { 性の欧善 }\end{array}$ & $\sim 0.3 \% \sim$ & \multirow{2}{*}{$\sim 0.5 \% \sim$} \\
\hline 18 & $"$ & $" \prime$ & $"$ & 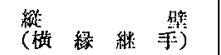 & $" 1$ & $12 \sim 18 \mathrm{~mm}$ & $" \prime$ & $"$ & $" \prime$ & $\sim 0.2 \% \sim$ & \\
\hline $1 \sim$ & 全 & 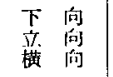 & 合 & 部 & - & - & - & - & $一$ & 26 & $\%$ \\
\hline & 注) & $\begin{array}{l}\text { UM : ユニ } \\
\text { OA : オー }\end{array}$ & $\begin{array}{l}\text { オンィルト法 } \\
\text { ブンアーク法 }\end{array}$ & $\begin{array}{l}\text { ES: エレクトロス } \\
\text { EG：エレクトロガ }\end{array}$ & $\begin{array}{l}\text { ラグ法 } \\
\text { ス法 }\end{array}$ & & & & & & . \\
\hline
\end{tabular}


長さの大なる船体ブロックでは，他の構造物と異なった 問題点もでてくるのである，表一6はもっとも一般的な 片面自動溶接を 3 種えらんでそれぞれの造船におりる得 失を諭じた結果である。これらには一長一短があってい
ちがいに櫌劣をきめるととができないが，筆者のととろ ではこのうちフラックスー銅バッキング法（神鋼 FCB 法）を使用している。この方法ではとけてみとか巨視的 ビード外観の点では良好な結果が得られ，全般的に中庸

表一6 片面自動溶接（ユニオンメルト法）におりる各種バッキング方法の得失

\begin{tabular}{|c|c|c|c|c|c|c|c|}
\hline \multirow{2}{*}{ ハッキング } & \multirow{2}{*}{ フラックス } & \multicolumn{3}{|c|}{ 閣 } & \multicolumn{2}{|l|}{ 題 点 } & \multirow[b]{2}{*}{ ららなみ形状 } \\
\hline & & 開 先 精 度 & ハシッキングの密着性 & 作 & 付 $\forall$ & 板 & \\
\hline 銅バッキング & 一般 用 & $\begin{array}{l}\text { 開先問隙の許容精度 } \\
\text { がややさびしい。 } \\
\text { 継手の直線度を要す } \\
\text { る。 }\end{array}$ & $\begin{array}{l}\text { 完全でなければなら } \\
\text { ない }\end{array}$ & \multicolumn{2}{|c|}{$\begin{array}{l}\text { ふつ5の仮付けでは } \\
\text { 問題にならない }\end{array}$} & $\begin{array}{l}\text { 板厚差に応じて当金 } \\
\text { 变え祀ばなら就い }\end{array}$ & 戙 \\
\hline $\begin{array}{l}\text { フラックスバッキ } \\
\text { ソグ }\end{array}$ & $\underset{\text { (神 }}{R F-1}$ & 竍容度が大 & 緩やがよい & \multicolumn{2}{|r|}{$" \prime$} & $\begin{array}{l}\text { 特別な妈置を淒しな } \\
\text { い }\end{array}$ & 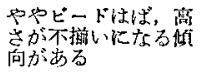 \\
\hline $\begin{array}{l}\text { フラックスー銅ハ } \\
\text { ッキッグ }\end{array}$ & $\begin{array}{l}\text { PFI-45 } \\
\text { (神)鋼) }\end{array}$ & 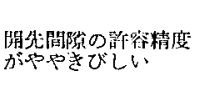 & $" 1$ & & $"$ & 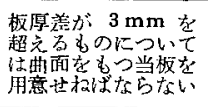 & 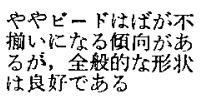 \\
\hline
\end{tabular}

表一７片面自動溶接法（神銅 FCB 法）に上る施工条件之能率面に与元る效果

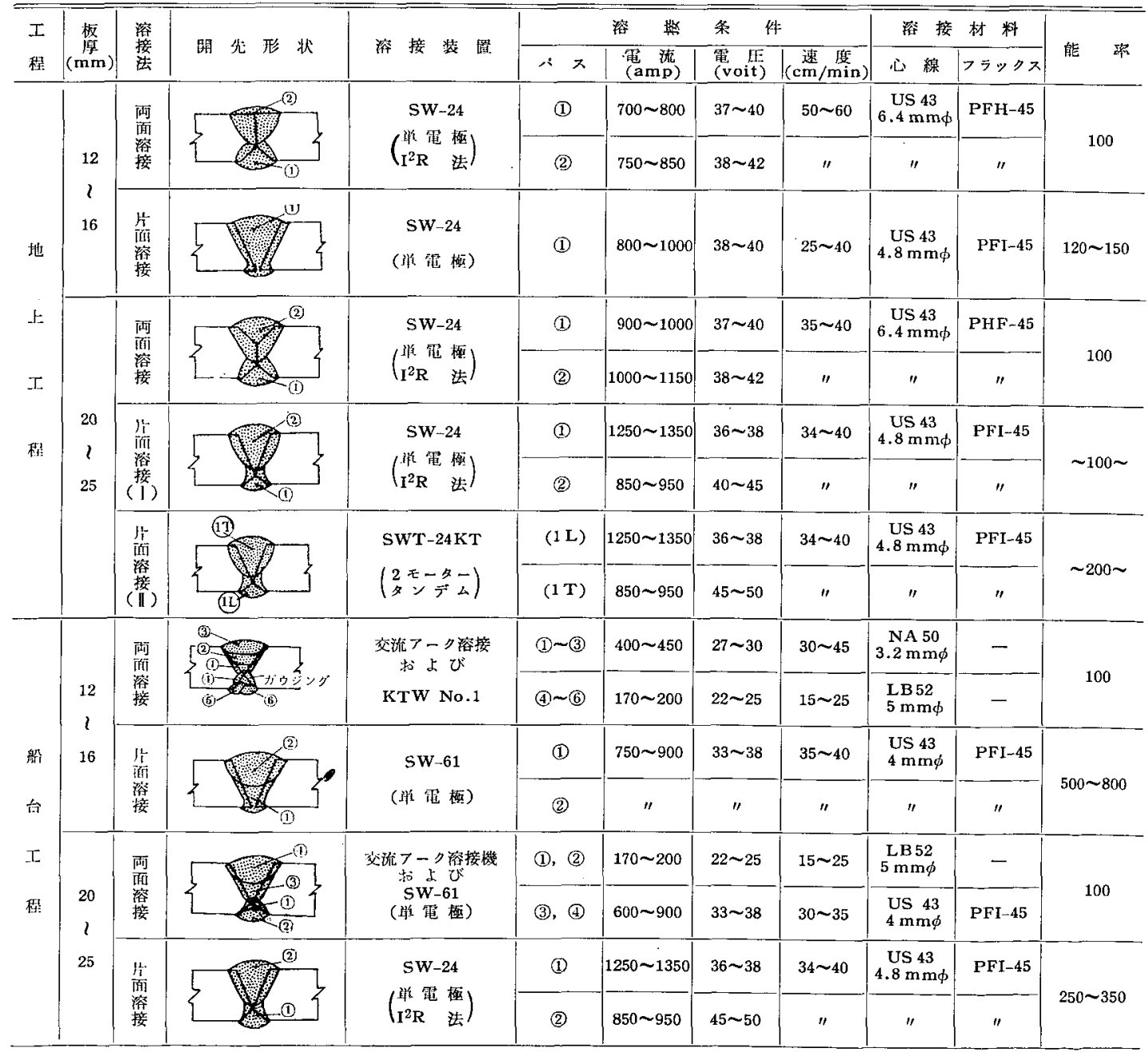


を得た感じであるととから選択の対象となったあのであ る。表一 7 はこの FCB 法を採用した場合の施工条件と 能率を示す。この表ではまず全体を地上と船台の 2 工程 に分けそ机ぞれを薄板 $(\mathrm{t}=12 \sim 16 \mathrm{~mm})$ と厚板 $(\mathrm{t}=20$ 〜25 mm）のグループに分けて报っているが，いまこの 結果を表の石端伅示す能㳯在中心にながめてみよう。

まず地上工程をながめた場合薄板のグループでは片面 自動溶接の採用で $20 \sim 50 \% の$ 能率向上がみられるが，厚 板ではおなじ単電極の溶接機を使用するかぎりでは能率 の向上は認められない。しかしてれに 2 モータータンデ ムの多電極用へッドを使用すれれば能率はいっきよに倍增 することになる。しかし実際には 2 モーターのタンデム では作業員が 2 人は必要であるからこの能率何上分は帪 消しとなり結局屯とのままということになる，てれに反 して船台工程の場合には雨面溶接の場合片側はどうして 屯上向资勢の手溶接となるから，ての点で比較の基準が 低能率となるのはま奴れず，てれを片面溶接とした之
きの能率向上はいちじるしく大となる。したがって以上 の結果加，地上と船台とではおなじ片面自動化とい。 てもおのずから重点の異なることがわかる。すすなわ地 上工程の場合片面自動化はいわば無反転型ともいうべき ものでこれは明らかに工程の促進を衫らったものであ り，船台工程のものは资勢変更型と屯いうべきもので，

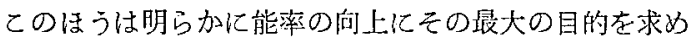
るととができるのである，

\section{2 高能率化 (高速度化)}

自動溶接を高能率化しょうという問題は従来しばしば 議諭の対象となってきている。なぜならば造船において 操業度を高めるのに neck point はつね稀とこような機 械設備への依存度の高い工程に求められるからである. そしてとれが兩面溶接加ら片面溶接へ上変換されると設 俑への依存度がますます高まると同時化，1 パスで上面 までいっきよに仕上らないときのスラグの㔀離性の不良 を除去したいという技術上の欲求加む，ての高能率化

表一8 自動溶接の高能率化のための諸策

\begin{tabular}{|c|c|c|c|c|c|c|}
\hline \multirow[b]{2}{*}{ 篭 } & \multirow[b]{2}{*}{ 漈接方法 } & \multirow[b]{2}{*}{ 施工法 の大要 } & \multirow{2}{*}{ 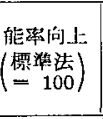 } & \multicolumn{3}{|c|}{ 作業管理上の间通点 } \\
\hline & & & & 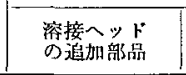 & 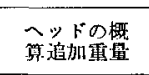 & 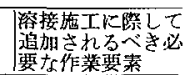 \\
\hline \multirow{4}{*}{$\begin{array}{l}\text { 機 } \\
\text { 械 } \\
\text { 工 } \\
\text { 程 }\end{array}$} & 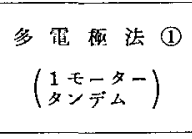 & 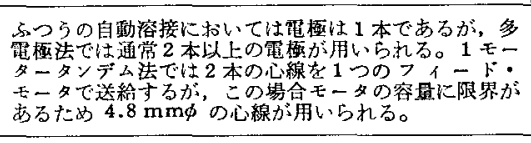 & 150 & 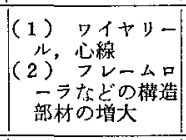 & $20 \mathrm{~kg}$ & 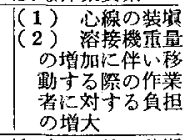 \\
\hline & 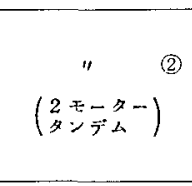 & 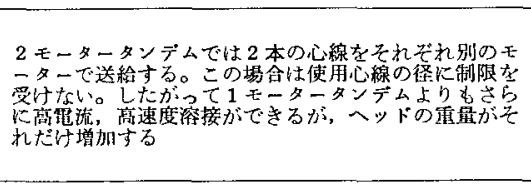 & 200 & 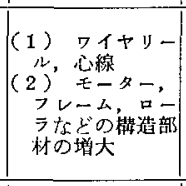 & $50 \mathrm{~kg}$ & 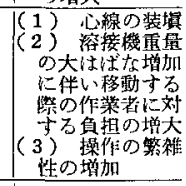 \\
\hline & $I^{2} R$ 法 & 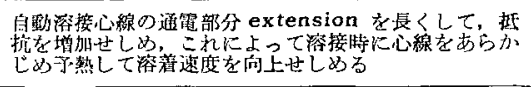 & 140 & $\begin{array}{l}\text { extension } \\
\text { 䂔治具 }\end{array}$ & $4 \mathrm{~kg}$ & 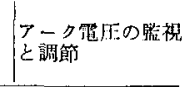 \\
\hline & 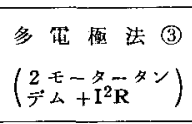 & 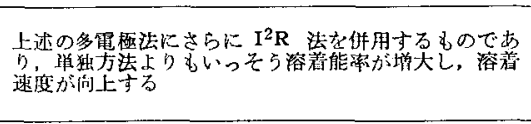 & $200 \sim 250$ & 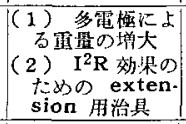 & $28 \sim 58 \mathrm{~kg}$ & 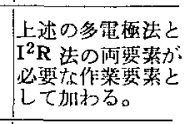 \\
\hline \multirow{5}{*}{ 治 } & $\begin{array}{l}\text { フイラメタル法(1) } \\
(\mathrm{KK}-\mathrm{F}, \mathrm{FN} \text { 法) }\end{array}$ & 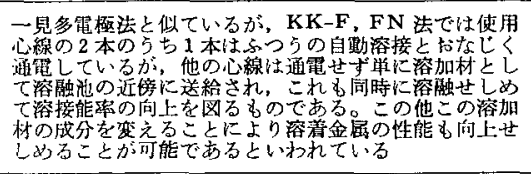 & 130 & 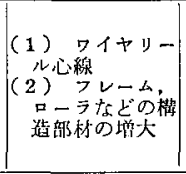 & $20 \mathrm{~kg}$ & 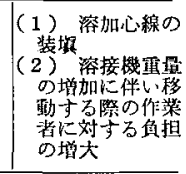 \\
\hline & " (2) & 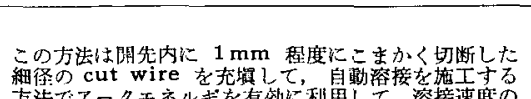 & & 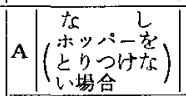 & $0 \mathrm{~kg}$ & 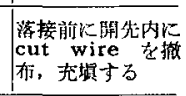 \\
\hline & (cut wire 法) & 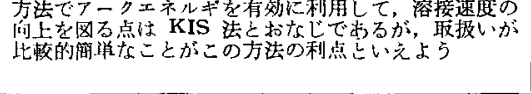 & 130 & \begin{tabular}{|l|l|} 
C cut Whre \\
月月ッペー
\end{tabular} & 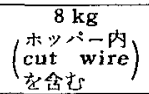 & 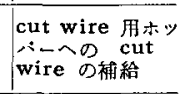 \\
\hline & $\left(\right.$ KIS 法) $^{\prime \prime}$ & 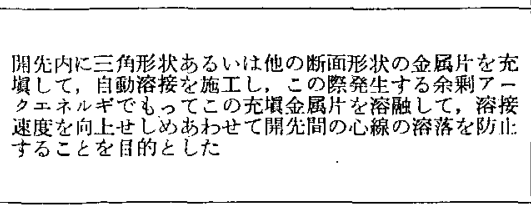 & 130 & な & $0 \mathrm{~kg}$ & 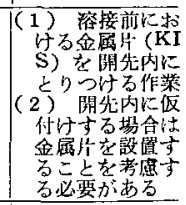 \\
\hline & 鉄粉棌加法 & 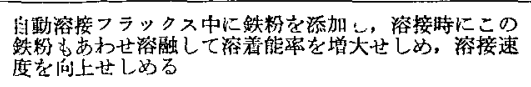 & 130 & な & $0 \mathrm{~kg}$ & 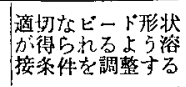 \\
\hline
\end{tabular}


の問題点はさらに大きく close up されたかたちとな る. 表一8はこの件について高能率化の方法を機械工程 之治金工程の 2 つに大別して, そのそれぞれにおける施 工法の大要を示すととあに, それらの結果得られる能率 向上の程度とさらにこれらを実施するに際して必要とな る付随作業の内容の詳細を記したあのである.

ちなみに筆者の造船所を例にとれば機械工程では軽量 自動溶接機以外にはすべて $\mathrm{I}^{2} \mathrm{R}$ 法を採用しており, 片 面自動溶接では 2 モータータンデムに $\mathrm{I}^{2} \mathrm{R}$ 法をつけて 使用している，また治金工程では cut wire 法ならびに 鉄粉添加フラックスを使用して能率の向上を計ってい る.ただし片面自動溶接ではうらなみビード形状を良好 にするためにはへッドの移動が一定速度範囲に押えられ るので, ある程度以上の高能率化は効果がないようで ある。

\section{3 溶接機の可般性の改善}

可般性の改善とはへッドの軽量化であると単純に考え るひとが多い，とくにメーカー関係に多いのはむりない としても, 造船所側での認識がこの程度にとどまるとと 自体に問題がのこる.われわれは可搬性の改善とはクレ ーンへの依存度の減少であるというととをしっかりと把 握する必要がある，そしててれを遂行するためには溶接 機の可般性のみを論じることなく,つねに溶接機の機能

（電源能力,ヘッドの堅审さなど）との関係において議 論されなけ札ばならない.たとえばユニオンメルト機で いかに軽いへッドをつくろうが, 1 パスで板厚が $15 \mathrm{~mm}$ までしかできないというのや, また半自動溶接へッドで たとえ $16 \mathrm{~kg}$ のものができようがひとたび高所から落 下すればこわれてしまうようなものではその造船での実
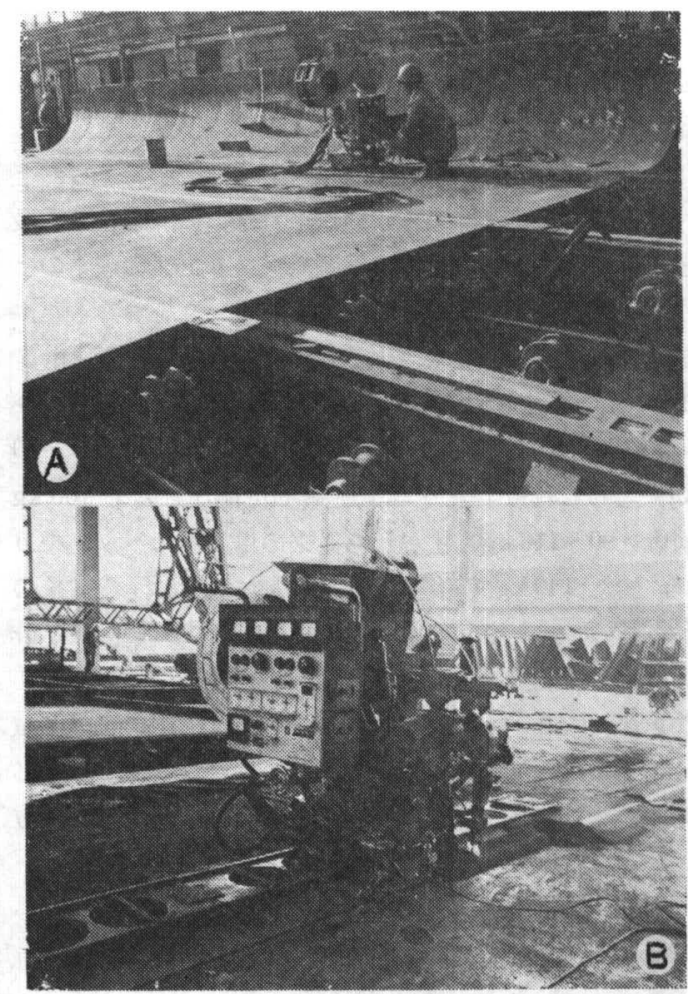

図一13 船体ブロックの片面自動溶接(®)とこれに 適用中の多電極- $\mathrm{I}^{2} \mathrm{R}$ 法用自動溶接へッド (B). このへッドは現在のところ溶融速度 の点から造船用としてはあっとも高能率と 考えられる.

用価值は最低にとどまる。

(1) ヘッドの軽量化

従来わが国メーカーのカタログではユニオンメルト機

表一9 造船用自動溶接機へッド（ユニオンメルト法）の可般性と性能

\begin{tabular}{|c|c|c|c|c|c|c|c|c|c|}
\hline \multirow[b]{2}{*}{ 級 } & \multirow{2}{*}{$\begin{array}{c}\text { ヘッド重量 } \\
(\mathbf{k g})\end{array}$} & \multirow{2}{*}{ 可 搬 性 } & \multicolumn{4}{|c|}{ 実 } & \multicolumn{3}{|c|}{ 例 } \\
\hline & & & 型 式 & $\begin{array}{c}\text { ヘッド重量 } \\
(\mathbf{k g})\end{array}$ & $\begin{array}{c}\text { 心 } \begin{array}{c}\text { 線 } \\
(\text { in. } \phi)\end{array} \\
\end{array}$ & $\begin{array}{l}\text { 最大電流 } \\
\text { (amp.) }\end{array}$ & 国 & xーカー & 用 途 \\
\hline \multirow{3}{*}{ A } & \multirow{3}{*}{$15 \sim 25$} & \multirow{3}{*}{$\begin{array}{c}1 \text { 人で運搬可能 } \\
\text { (容易) }\end{array}$} & A-2 & 18 & $5 / 64 \sim 1 / 8$ & 600 & スエーデン & ESAB & 下向専用型 \\
\hline & & & SW-61 & 22 & $3 / 32 \sim 5 / 32$ & 900 & 日本 & 大 㙥 & $"$ \\
\hline & & & SW-81 & 25 & $3 / 32 \sim 3 / 16$ & 1000 & $"$ & " & 下向, 横向 \\
\hline \multirow{3}{*}{ B } & \multirow{3}{*}{$30 \sim 40$} & (やp”困難) & HSA $80 \mathrm{PT}$ & 32 & $1 / 8 \sim 5 / 32$ & 800 & スエーデン $\mid \mathrm{I}$ & Hägglunds & 下向専用型 \\
\hline & & \multirow{2}{*}{$\begin{array}{c}2 \text { 人で運搬可能 } \\
\text { （容易） }\end{array}$} & AS-5 & 40 & $3 / 32 \sim 1 / 8$ & 600 & ベルギー & ARCOS & " \\
\hline & & & TS-17 R & $"$ & $1 / 16 \sim 3 / 16$ & 1000 & 連 & - & 下向, 横向 \\
\hline \multirow{4}{*}{ C } & \multirow{4}{*}{$45 \sim 70$} & \multirow{2}{*}{ (や”困難) } & LAF-II & $40 \sim 45$ & $5 / 32 \sim 7 / 32$ & 1200 & 国 & Lincoln & 下向専用型 \\
\hline & & & SW-41 & 50 & $3 / 16 \sim 1 / 4$ & 1300 & 本 & 大 変 & 下向, 横向 \\
\hline & & \multirow{2}{*}{ （非常に困難） } & ADS $1000-2$ & 65 & $1 / 8 \sim 1 / 4$ & 1200 & 連 & - & $"$ \\
\hline & & & AS-4 & 70 & $3 / 32 \sim 3 / 16$ & 800 & ベルギー & ARCOS & $"$ \\
\hline D & $90 \sim 110$ & 人力で運搬不可能 & $\begin{array}{l}\text { 米国 (Lino } \\
\text { の級に属す }\end{array}$ & $\begin{array}{l}\text { de 衤), 昌 } \\
\text { る (例: U }\end{array}$ & 各 $\mathrm{x}$ - & 単電極用と & て従来販売し & してきたものは & すべてこ \\
\hline $\mathbf{E}$ & $120 \sim 160$ & $"$ & $"$ & (例 : $\mathrm{S}$ & - 24, GI-B & $\begin{array}{l}2 \text { 電極用と } \\
\text { GI-D) }\end{array}$ & て見在眅売し & てているあのは & " \\
\hline
\end{tabular}


にかぎらず, すべての溶接機でヘッドの重量を記したも のはなかったそそしててれについて質問しても自社の製 品についてすら確たる回答を求めることはできなかっ た.つまりこの点についてはまったく無関心であったと いわれてもしかたはあるまい，筆者はこの点の啓蒙手段 として溶接へッドの重量を䋅闘やレスリングの選手のよ うにランキングするととを考えて, 表一 9 をつくった. まず 1 人で容易に運搬できるものを A 級 (15 25 kg), 1 人ではやや困難だが 2 人では容易なあのを $\mathrm{B}$ 級 (30〜 $40 \mathrm{~kg}), 2$ 人ではやっと屯てるというのを C 級 (45 70 $\mathrm{kg})$ としこれ以上人力では運般不可能なむのを $100 \mathrm{~kg}$ 前後 $(90 \sim 110 \mathrm{~kg})$ すなわち従来の単電極のヘッドをD 級, また $140 \mathrm{~kg}$ 前後 $(120 \sim 140 \mathrm{~kg})$ すなわち従来の 多電極のヘッドを $\mathrm{E}$ 級として全体をこの 5 コの階級に分 類しその性能の優劣を比較した. 表一 8 をつくった当初

(すなわち 2 年まえ) は A, B,C 級には国産のものは 1 台もみあたらなかったものである。しかしこのような必 要性のくりかえしてのPRによる刺激はしだいにメーカ
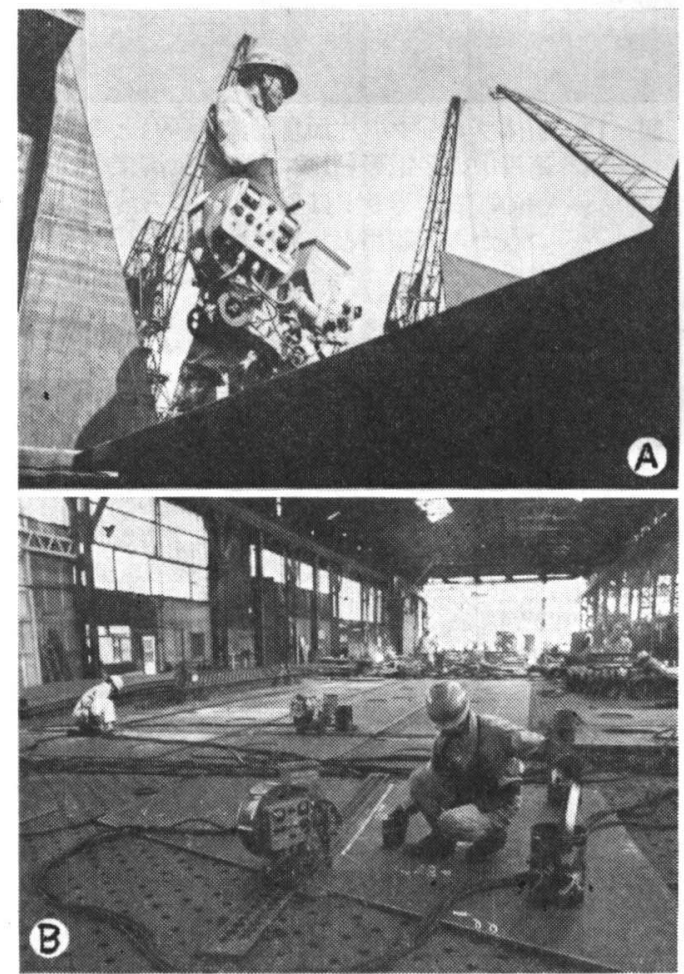

図一14 小型軽量化されたユニオンメルト、ヘッド 重量はわずか $22 \mathrm{~kg}$ であるが，外国製品に ありがちな「小型化による機能の低下」の ないところがすぐれている（定格電流 900 amp., 心線径 5/32吋). (A)船台上でヘッ ドを運搬中，Bは小組立に際して活用中の 状況.
一側に浸透しこれに筆者をはじめとする造船所側の orientation が付加されて，いまでは表に示すどとく国 産のものは外国製品をはるかにぬいて優れた存在となっ ている.

（2）船台上における可搬性の改善

船台上の場合ほど可搬性に対する認識のひくいものは ない. なるほど定盤上においては溶接電源の多くは固定 されているから，ヘッドの軽量化はそのままクレーンへ の依存性を大はばにひくめることができた。しかし船台 上においてはこの前提条件はまったくあてはまらない. したがってクレーンの使用回数は 1 つの区画に少なくも 1 回は必要なのであるから, ヘッドの軽量化に走るより むむしろ溶接装置に局部的な自走装置をつけることのほ うが可搬性の改善に役だつととになる，図一15はこれら に対する筆者のこころみのひとつを示すむのであって， 上甲板ブロックまたは側部タンクの中間フラットをおい てから側外板のバットやシームを溶接するには，このよ うに専用化された機器は機能の低下をみずに有効に活用 されることになろう。いっぽうこれに反してある種の外

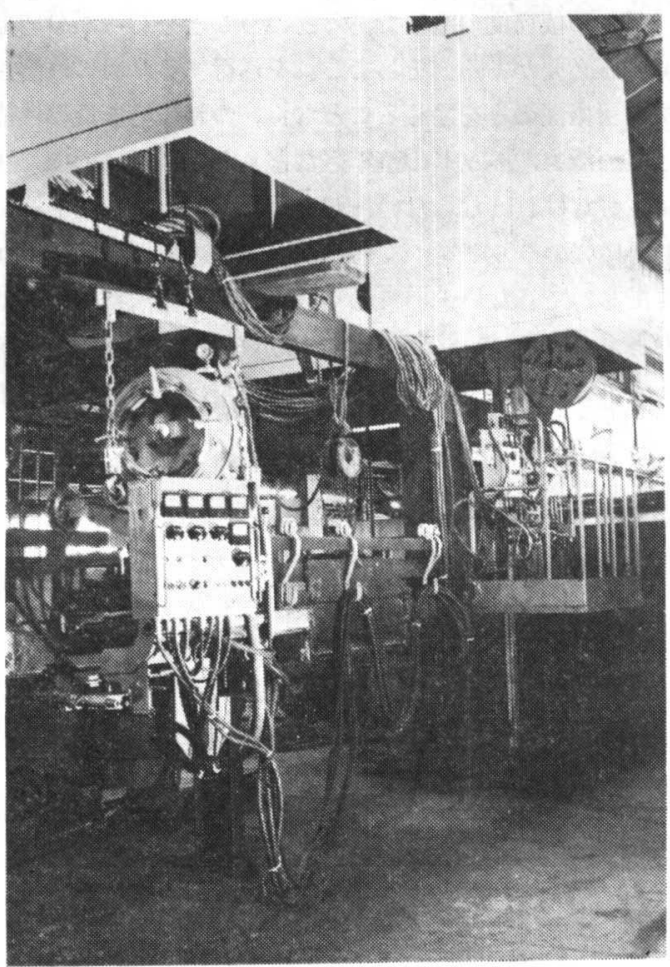

図一15 setting に際しクレーンの依存度圭減少さ せることを目的として筆者の orientation により製作された造船用溶接装置（立向自 動溶接機ならびに横向自動溶接機), いず あれ船台工程における可搬性が大はばに改 善されている. 
国製品ではへッド重量わずかに $5 \mathrm{~kg}$ というエレクトロ スラグ溶接機があるが, 機能の低下が大きいととを考え るとこれらは現状のままではとて屯造船の現場では使い あのにならない.

\section{4 対傾斜性の改善}

造船に溶接が導入された結果近代化がなされたとする ならば，その最大の要素はまずブロック建造法にもとづ く地上工程の確立に求められ, つぎにての地上工程にお いて造船への流れ作業の導入のいとぐちとなった枠組工 法の採用に指を屈しなければならない。しかし船体が流 体中を推進する運動体であるからには必然的に流線型を とらざるを得ず，したがってその前後部には多くの曲面 ブロックが生じるととになる。 そして上述の枠組工法は 従来船体平行部分にのみ適用されており, これらの曲面 ブロックについては例外的に個別製品生産方式をとらざ るを得なかった。

いわゆる曲り外板の自動溶接の成功は板つぎ工程の分 離を要するところから当然他の平板ブロックと同様の工 法を実施することになり，乙れに刺激されて組立技術上 の多くの点が改良された結果, 造船ははじめて全面的に 流れ作業に依存する近代産業としての第 1 歩を印すとと になる、そしててれの原動力となったフラックスの開発 にあたって筆者の与えた指針は単に「近代化」の根本原 則とされる「専用化」を方法としたにすぎない，表一10 は開発の結果もたらされた曲り外板ブロックの板つぎに 刘する自動溶接の施工条件を示す.

なお機械装置の面ではもちろん前述のへッドの軽量化 が問題となるが，てれに加えるにへッドに登はん性を与. えるためにはアプト式鉄道のようにレールにラックをつ けてすべりどめ装置を施す必要があろう。

3.5 半自動溶接の実用化
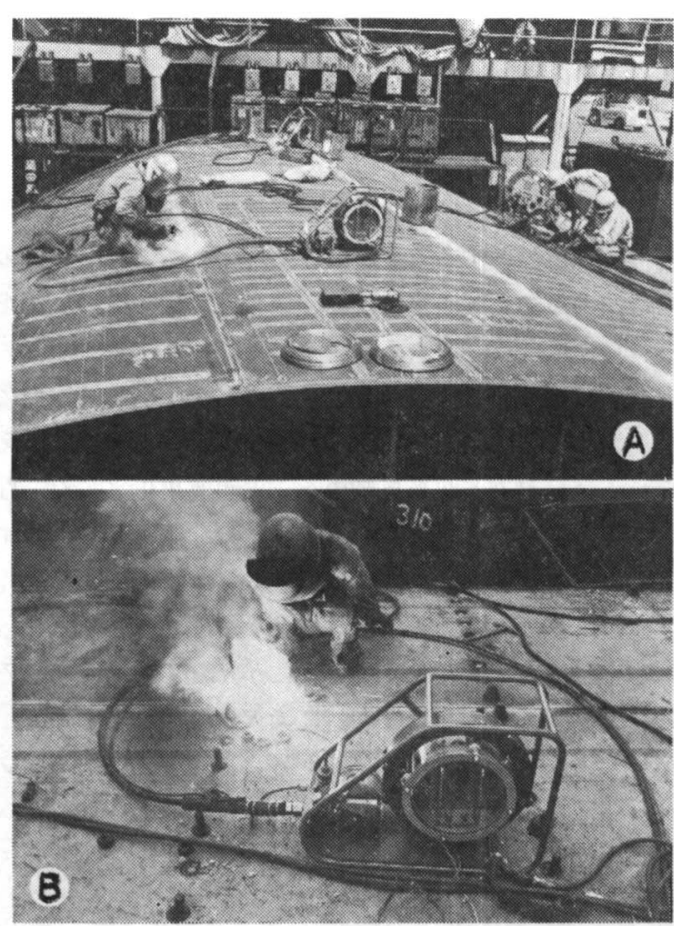

図一16 造船に活用されるオープンアーク式半自動 溶接（®：曲り外板の自動溶接のための下 あり溶接, B：舵構造のエレクションボル トのはめこみ溶接). 自動化困難な継手は すべてとの方法で近代化されていく. ヘッ ドは筆者の orientationにより造船所向き の堅牢かつ実用的な構造と機能を有してお り, しかも可般性改善の点からへッド重量 を $18 \mathrm{~kg}$ に押えるのに成功した。

半自動溶接の実用化の問題点にはもちろん前述のへッ ドの軽量化が入る. しかしての他の問題点としては従来 $\mathrm{CO}_{2}$ ガスアーク溶接が造船にとり入れられなかった最大

表一10 曲り外板の板つぎに対する自動溶接（ユニオンメルト法）の適用条件の 1 例

\begin{tabular}{|c|c|c|c|c|c|c|c|c|c|}
\hline \multirow{2}{*}{ ブロック } & \multirow{2}{*}{$\begin{array}{c}\text { 開 先 形 状 } \\
(\mathrm{t}=20 \mathrm{~mm} \text { の㛫合 })\end{array}$} & \multirow{2}{*}{ 倾 斜 } & \multicolumn{2}{|r|}{ 溶 } & \multicolumn{2}{|l|}{ 条件 } & \multicolumn{2}{|c|}{ 溶 接 材 料 } & \multirow{2}{*}{ 借者 } \\
\hline & & & パス & 電流 (amp.) & 電压(volt.) & $\begin{array}{l}\text { 速 } \\
(\mathrm{mm} / \mathrm{min} .\end{array}$ & 心 線 & フラックス & \\
\hline \multirow[t]{2}{*}{ 平 } & & \multirow{2}{*}{$0^{\circ}$} & B P & $\begin{array}{c}750 \sim 800 \\
(800 \sim 850)\end{array}$ & $\begin{array}{c}33 \sim 35 \\
(38 \sim 40)\end{array}$ & $\begin{array}{c}330 \sim 350 \\
(400 \sim 450)\end{array}$ & US 43 & PFH 45 & \multirow{2}{*}{$\begin{array}{l}\text { （）内数字 } \\
\text { は } \mathrm{I}^{2} \mathrm{R} \text { 法 } \\
\text { (KK-X法) } \\
\text { による場合 } \\
\text { を示す. }\end{array}$} \\
\hline & & & F P & $\begin{array}{c}1000 \sim 1050 \\
(1100 \sim 1150)\end{array}$ & $\begin{array}{c}34 \sim 36 \\
(38 \sim 42)\end{array}$ & $\begin{array}{c}280 \sim 300 \\
(350 \sim 400)\end{array}$ & $" \prime$ & " & \\
\hline \multirow{6}{*}{$\begin{array}{l}\text { 曲 } \\
b \\
\text { 外 }\end{array}$} & & \multirow{2}{*}{$0^{\circ} \sim 3^{\circ}$} & B P & $850 \sim 900$ & $35 \sim 37$ & $180 \sim 200$ & $\prime \prime$ & PFI 45 & \multirow{6}{*}{$\begin{array}{l}\text { B P 側 : } \\
\text { オーブンフー } \\
\text { ク法でシーリ } \\
\text { ングビートを } \\
お く . \\
\text { F P 側 : } \\
\text { ガウシシンク }\end{array}$} \\
\hline & & & F P & $800 \sim 850$ & $36 \sim 38$ & $350 \sim 400$ & $\prime \prime$ & PFH 45 & \\
\hline & & \multirow{2}{*}{$3^{\circ} \sim 5^{\circ}$} & B P & $750 \sim 800$ & $33 \sim 36$ & $150 \sim 160$ & " & PFI 45 & \\
\hline & & & F P & $700 \sim 750$ & $35 \sim 37$ & $330 \sim 350$ & $"$ & PFH 45 & \\
\hline & 54 & \multirow{2}{*}{$5^{\circ} \sim 10^{\circ}$} & B P & $700 \sim 750$ & $33 \sim 35$ & $140 \sim 150$ & $" \prime$ & PFI 45 & \\
\hline & & & F P & $600 \sim 650$ & $3 \dot{3} \sim 35$ & $300 \sim 320$ & " & PFH 45 & \\
\hline
\end{tabular}


の理由はシールドガスのためノズルが太くなり作業性が 悪くなるのと, 風によりシールドガスが拡散するととの 2 つが致命傷としてあげられる.

オープンアーク溶接が以上のすべての点に有利である ことは論をまたないし，乙れが交流でしかるふつうの手 溶接機を電源とするととができる場合，あとはへッドの 可搬性の点さえ解決すればその機動性は数十倍の価値を あつととになろう。

筆者の orientation がこれらの点に集中されて強力に 推進された結果, 図一16亿示す完全に造船所むきと考え られるコンパクトな半自動用ヘッドが実用化された。な おこのへッドは重量は $18 \mathrm{~kg}$ で他の同種製品の $1 / 3$ にす ぎないが，少なくも $5 \mathrm{~m}$ の高さからの落下衝撃によく 堪えるほか，たとえもっとあデリケートな制御部分に故 障が生じてもこれはりケット式にかんたんにぬきだせる ので予備回路さえあれば即時に素人にあ修繥できる。し かしこの部分はドラムとワイヤさらにその外側をパイプ
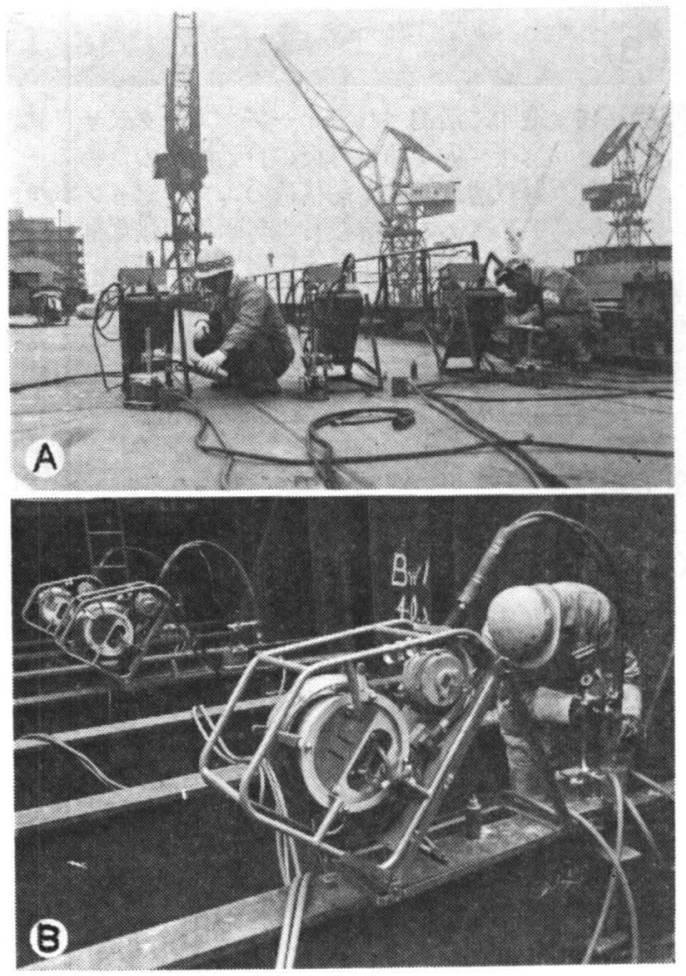

図一17 船台溶接の自動化は造船現業部門の溶接技 術者の今後の最大の課題である. 消耗ノズ ル式エレクトロスラグ法もその 1 つであり 多くの技術的難点を克服して実用化がすす められていく(®) : 表一1, 第16群, (B): 表一1，第15群）。なおへッドは半自動溶 接用のあのがそのまま適用されているので 可般性その他に問題はない.
支構で保護されているのでめったなととでは故障しない 構造となっている.

またとのへッドは図一17亿示すようにそのまま消耗ノ ズル式エレクトロスラグ法にあ転用できるため, 筆者の 造船所ではすでに神戸工場のみで35台（この数字は現在 の日本の造船所のもつすべての $\mathrm{CO}_{2}$ ガスアーク溶接用 ヘッドの半分以上にあたる) のあのが使用されている.

\section{4. 自動化推進の過程}

さきに表一 5 に自動化の範囲とそれにとあなう問題点 について示したが，ここではそれを実際に推進した量的 過程について述べよう.さて自動化を推進する場合, そ の効果には表一 3 (第 2 章) に示したように能率の向上 , 工程の促進, 熟練の移転, 品質の向上の各因子があり 特にはじめの 2 因子が作用して実際の周辺条件は絶えず 変ることになる．たとえば図一18は横軸に自動溶接機の 台数をとり, 縦軸に自動化率をとって, 自動化の推進に は溶接機の設備が大きく影響することを示すが, いっぽ う自動化の推進は能率の向上により工数の相対的減少を あたらすとともに工程を促進して操業度を向上させた結 果, 生産量 (月間加工重量) をむ大はばに増大させるこ とを示している. またこの推進の過程は第 3 章にあ述へ たように段階的に拡大されているため, 推進の各過程と 適用範囲の量的関係は経験的によく把握されており, そ の内容が曲線の右側に実績として記入されている.なお 図一18には月間加工重量が 1,000 ton あたりの溶接機台 数を比溶接機台数として参考までに記入したが，これは 全国造船所の平均自動化率 $(12.3 \%)$ のとろで 3.0 台 $/ 10^{3}$

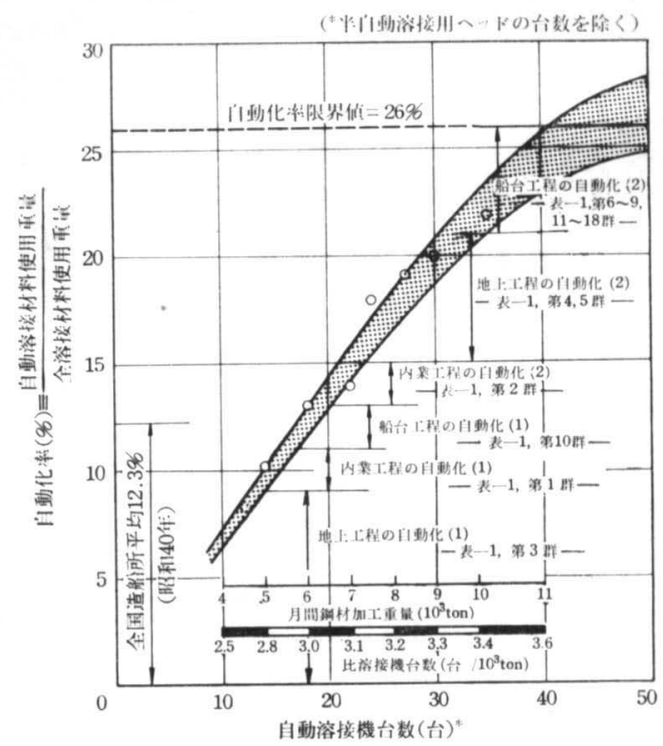

図一-18 溶接自動化の進展過程を示す具体例 (川重神戸) 
ton こなり，乙れまた全国平均值とよく一致している.

\section{5.あとがき}

従来造船溶接の自動化に関连して多くの報告が発表さ れている.そしてそれらに使用された個别的な方法はい ずれも例外なく能率の向上をねらうための有力な手段之 してはなばなしく喧伝されている.しかし筆者はこと造 船に関するかぎりでは，1つや2つの新しい技術が造船 の全工程にわたって決定的な効果を示すほど造船は単純 な生産機構をむつものではないと考えている。そしてて の結果自動化といってもこれは単にある1つの䒾置的な 方式で求められるととろの automation of welding (溶 接のオートメ化) ではなく，各種の自動溶接を綜合して 推進するととろの promotion of automatic welding (自動溶接の推進) だあると信じている、したがって造
船溶接の自動化においては個々の溶接法をミク口的に労 明するととはもちろん大切な技術的アプローチとされる けれよ゙す，終局的には多くの方法を洒值尔析してこれら をマクロ的見地にたって取捨選択する態度はより重要な アプローチの方法として認めなければならない.

このような見地からしててとにまとめた事例研究では 問題点を綜合的にとり上げるべく，主ししてそれの発生 するにいたった周辺条件の記述に意をそそぐし同時に問 題点の輪郭を明らかにするよう努力し, 問題点個々の解 決はむしろ読者の判断にゆだ水るへくくれを誘導してい くことに重点をおいた。そしててれはよりもなおさず第 3 章において筆者の指摘した 2 次的技郝者がメーカー㑡 に与える 1 次的 orientation の1つのよき例にほ加なら ないと考えるのである。

\section{次号予 告}

\section{講義}

塗装と溶接

明石重焳

\section{資}

料

最近にお㚈る高能率溶接法実用化の動问上溶接自動化の面からみた 評価基準について

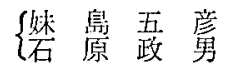

\section{論文および報告}

ニッケル基耐䅉酸合金の溶接

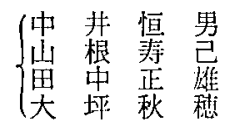

プラズマジェットの特性に関する䟭（第 1 報）

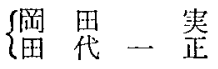

$\mathrm{CO}_{2}-\mathrm{O}_{2}$ アーク溶接法による锅材溶接部の衝揧值（第 1 報）

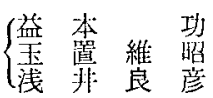

アルミニウム合金然処理板用点溶接法の掐音波利用の研巟(第 1 報)

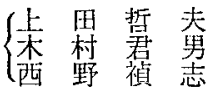

念 AIN 鈵の溶接性に関する研究（第。1 報）

低温用銅材の $\mathrm{CO}_{2}-\mathrm{O}_{2}$ アーク溶接について（第 1 報）

\section{I.I.W. および J.I.W.}

疲労履歷を受けた原寸構造物試験片のぜい性破流 藤 投 英 輔

文献 紹 介 